\title{
Effects of Hibiscus Sabdarrifa L. Anthocyanins on Cadmium-Induced Oxidative Stress in Wistar Rats
}

\author{
*ORORORO, OC; ASAGBA, SO; TONUKARI, NJ; OKANDEJI, OJ; MBANUGO, JJ \\ Department of Biochemistry, Delta State University, Abraka, Nigeria. \\ *Corresponding author. E-mail: osuvwec@yahoo.com,Tel: +2348062306783
}

\begin{abstract}
The search for potential ameliorative substances of Cadmium (Cd) toxicity is ongoing. Thus, this study was aimed at investigating the effects of Hibiscus Sabdarrifa L. anthocyanins (HSA) on Cd-induced oxidative stress in wistar rats. Anthocyanins were extracted from $H$. sabdariffa calyces using standard protocols and were identified with a Agilent HPLC system (model-LC 1100 series).Thirty wistar rats (185 $\pm 5.2 \mathrm{~g}$ ) divided into Five (5) groups and were treated for fifteen days: Group 1: control, Group 2: Cd alone, $3 \mathrm{mg} / \mathrm{kg}$ b wt, Group 3: HSA alone, $3 \mathrm{mg} / \mathrm{kg}$ b wt, Group 4: HSA Pre-Cd - HSA ( $3 \mathrm{~g} / \mathrm{kg}$ b wt for ten consecutive days) and Cd (3mg/ $\mathrm{kg} \mathrm{b} w \mathrm{w})$ for the remaining five days, Group 5: HSA Post-Cd - Cd $(3 \mathrm{mg} / \mathrm{kg} \mathrm{b} \mathrm{wt})$ for the first five consecutive days then HSA $(3 \mathrm{~g} / \mathrm{kg} \mathrm{b} \mathrm{wt})$ for the remaining ten days. Comparison of HPLC chromatogram of anthocyanin extract of $H$. sabdariffa calyces with published data revealed the presence of malvidin-3-O-glucoside, delphinidin-3-monoglucoside, cyanidin-3-monoglucoside and petunidin-3monoglucoside. Exposure to Cd significantly reduced $(\mathrm{p}<0.05)$ GSH levels and glutathione-s-transferase activity but significantly $(\mathrm{P}<0.05)$ increased lipid peroxidation in the plasma and tissues of rats. Cd-exposure also caused a significant decrease $(\mathrm{p}<0.05)$ in tissue SOD and CAT, but pre-treatment and post-treatment with HSA improved tissue SOD, CAT and GST activitieswith concomitant increase in GSH levels and reduction in tissue lipid peroxidation. This confirms the antioxidant capacity of $H$. sabdariffa anthocyanins in ameliorating Cd-induced oxidative stress when administered pre and post Cd exposure.
\end{abstract}

DOI: https://dx.doi.org/10.4314/jasem.v22i4.4

Copyright: Copyright (C) 2018 Orororo et al. This is an open access article distributed under the Creative Commons Attribution License (CCL), which permits unrestricted use, distribution, and reproduction in any medium, provided the original work is properly cited.

Dates: Received: 04 March 2018; Revised: 27 March: 2018; Accepted: 04 April 2018

Keywords: Lipid Peroxidation, Catalase, Glutathione, antioxidants

Cadmium is a non-essential toxic heavy metal. Its widespread use in electroplating, production of battery, pigments, plastics, fertilizer and other industrial products as resulted in the contamination of the environment, affecting human health through occupational and environmental exposure (Embugushiki et al., 2013; Onwuka et al., 2010; Gaurav et al., 2010). Its long biological half-life (up to 30 years) coupled with its low excretion rate increases its toxicity as it bio-accumulate in tissues with the liver and kidney being principal targets (Rani et al., 2014; Yang and Shu, 2015). Upon entrance into cells, Cd accumulates highly in the nucleus and cytoplasm (Andujar et al., 2010).Cd-induced toxicity is mediated through different routes in cells and tissues such as oxidative stress and interaction between $\mathrm{Cd}$ and essential metals (Vesey, 2010; Cuypers et al., 2010). Oxidative stress caused by $\mathrm{Cd}$ occurs via increase in reactive oxygen species such as singlet oxygen, hydroxyl radical and hydrogen peroxide, which alter tissue antioxidant defense systems and contribute to oxidative stress by increased peroxidation of membrane lipids, mutations in DNA, gene expression alterations and apoptosis (Ognjanovic et al., 2010). Thus, Cd-induced oxidative stress can be detected by monitoring the activities of glutathione peroxidase, superoxide dismutase, catalase and tissue levels of malondialdehyde (Jabeen and Chaudhry, 2011).

Chelating compounds such as calcium disodium versenate, dimercaprol and mesomercaptosuccinic acid have been used in treating cadmium intoxications and these yielded varying results (Aaseth et al., 2016). However, some safety and effectiveness concerns about these chelators have been reported such that no chelating therapy in ameliorating Cd toxicity has so far been approved for clinical use (McCarty, 2012). This has led to the search for the development of safe and efficient strategies against $\mathrm{Cd}$ toxicity (Callegaro et $a l ., 2010)$ and in this regard, the attention of researches has been drawn to the potential of different plant antioxidants and poly-phenolic compounds such as anthocyanins, which have been reported to provide chemo-protective effects that combat oxidative stress in the body (Abeda et al., 2015, Miguel, 2011). Anthocyanins are members of the flavonoid family with a distinctive $\mathrm{C} 3-\mathrm{C} 6-\mathrm{C} 3$ carbon structure found widely in fruits, flowers and vegetables (Abeda et al., 2015). Hibiscus sabdariffa Linn also known as Roselle or red Sorrel is a member of Malvaceae family widely 
grown in Central and West Africa. Its extracts have been shown to possess antioxidant properties attributed to the presence of anthocyanins (Al-Groom and Al-Kubaisy, 2016; Ologundudu et al., 2010). The present study is thus aimed at investigating the ameliorative effects of Hibiscus Sabdarrifa $L$. anthocyanins (HSA) pre and post treatment on cadmium-induced oxidative stress in wistar rats.

\section{MATERIALS AND METHODS}

Chemicals: The reagents used in this study were of analytical grade. Cadmium Chloride, methanol, trichloroacetic acid, acetonitrile and sodium chloride were purchased from Lobal Chemic Laboratory Regents and Fine Chemicals, Mumbai - India. 2,thiobarbituric acid, Dichromate, acetic acid, adrenaline, and Ellman's reagent were gotten from BDH Chemical Company (Poole, England).

Plant Material: Fresh calyces of $H$. Sabdariffa L. were obtained from Warri Main Market, Warri South L.G.A., Delta State and were identified by a specialist in the Department of Botany, Delta State University, Abraka. Thereafter, they were dried under continuous air-flow maintained at room temperature until constant weight was achieved.

Extraction and Purification $H$. sabdariffa anthocyanins: Anthocyanins were extracted from $H$. sabdariffa calyces according to the method of Hong and Wrolstad (1990) with sight modification as reported by Ologundudu et al., (2010). The extraction began by pulverization of one (1) $\mathrm{kg}$ of $H$. sabdariffa calyces. The pulverized calyces were then extracted using ten litres of $0.1 \%$ trifluoroacetic acid (TFA) for a period of twelve hours at $40^{\circ} \mathrm{C}$. Thereafter, the extract was filtered with Whatman No. 1 filter paper and the filtrate was applied to silica-gel resin column (120 mesh) for fractionation of the different compounds in the extract. The resin bed became red as it absorbed anthocyanins while sugars, acids and other water-soluble compounds were washed off with three litres of water. Anthocyanin pigments were thereafter eluted with $50 \%$ ethanol solution containing $0.1 \%$ TFA. The resulting eluate was dried at $40^{\circ} \mathrm{C}$ under vacuum to obtain a concentrated eluate, which was then was subjected to high-speed liquid chromatography (HPLC) to identify the purified anthocyanins and other active principles. This was done according to the method described by Drust and Wrolstad (1990) using Agilent HPLC system (modelLC 1100 series).

Experimental animals: Thirty (30) adult male wistar rats weighing $185 \pm 5.2 \mathrm{~g}$ were used for the study. The rats were obtained from the animal house of the
University of Nigeria, Nsukka. Before the experiment commenced, the rats were kept in spacious rooms with temperature of $25 \pm 2{ }^{\circ} \mathrm{C}$ and $12 \mathrm{~h}$ light/dark lightening system to acclimatize for one week and were fed with clean water and feed ad libitum.

Experimental Design and Treatment of animals: Experimental rats were divided into Five (5) groups; Group 1: control, Group 2: Cd alone, $3 \mathrm{mg} / \mathrm{kg}$ b wt, Group 3: HSA alone, $3 \mathrm{mg} / \mathrm{kg}$ b wt, Group 4: HSA Pretreatment: HSA ( $3 \mathrm{~g} / \mathrm{kg}$ b wt for ten consecutive days) and $\mathrm{Cd}(3 \mathrm{mg} / \mathrm{kg} \mathrm{b} \mathrm{wt})$ for the remaining five days, Group 5: HSA Post-treatment: Cd (3mg/kg b wt) for the first five consecutive days then HSA $(3 \mathrm{~g} / \mathrm{kg}$ b wt) for the remaining ten days. $H$. sabdarrifa anthocyanin and cadmium (in form of aqueous solution) were administered to the animals orally by orogastric tube. The animals were treated for 15 days. At the end of the treatment period, the animals were sacrificed by cervical dislocation. Blood samples were obtained by cardiac puncture into heparinized bottles and centrifuged at $3000 \mathrm{~g}$ for $10 \mathrm{~min}$. From each rat, the liver and kidney were obtained, weighed and $1 \mathrm{~g}$ portion homogenized in ice-cold saline $(1: 4, \mathrm{w} / \mathrm{v})$ and centrifuged at $5000 \mathrm{~g}$ for $10 \mathrm{~min}$. Sera collected was stored frozen until used for biochemical analysis.

Biochemical Assays: Determination of Catalase Activity: The method of Singha (1972) was used for the determination of Catalase activity of samples. In performing the assay, different amounts of $\mathrm{H}_{2} \mathrm{O}_{2}(10$ to $100 \mu$ moles) were put into small test tubes and $2 \mathrm{ml}$ of dichromate/acetic acid was added to each. This immediately produced an unstable blue precipitate of perchromic acid. Thereafter the solution mixture was heated for 10 minutes in boiling water. This changes the colour of the solution to stable green due to formation of chromic acetate. Then, the volume of the reaction mixture was made to $3 \mathrm{ml}$ after cooling at room temperature. The optical density was then measured at $570 \mathrm{~nm}$ with a spectrophotometer. A standard Catalase curve was obtained by plotting the concentrations of the standard against absorbance.

Determination of Superoxide Dismutase Activity: The method of Misra and Fridovich, (1972) was employed in determining SOD activity in samples based on the inhibition of the autoxidation of adrenaline at $\mathrm{pH} 10.2$ by superoxide dismutase. First, a 1 in 10 dilution of the sample was prepared by dilution $1 \mathrm{ml}$ of sample in $9 \mathrm{ml}$ of distilled water. Then an aliquot $(0.2 \mathrm{ml})$ of the diluted sample was added to $2.5 \mathrm{ml}$ of $0.05 \mathrm{M}$ carbonate buffer $\mathrm{pH} 10.2$ to equilibrate in the spectrophotometer. Thereafter, reaction was started by the addition of $0.3 \mathrm{ml}$ of freshly prepared $0.3 \mathrm{mM}$ adrenaline to the mixture and was mixed quickly by inversion. A blank 
curette was also prepared containing $2.5 \mathrm{ml}$ buffer, $0.3 \mathrm{ml}$ of substrate (adrenaline) and $0.2 \mathrm{ml}$ of distilled water. The increase in absorbance at $480 \mathrm{~nm}$ was monitored every 30 seconds for 150 seconds and calculated as:

Increase in absorbance per minutes $=\frac{A_{3}-A_{0}}{2.5}$

\%Inhibition $=100-$

$\frac{\text { increase in absorbance for substance }}{\text { Increase absorbance for blank }} \times 100$

One unit of SOD activity of being the amount of SOD necessary to cause $50 \%$ inhibition of the oxidation of adrenaline to adenochrome during 1 minute.

Estimation of Reduced Glutathione Level (GSH) level: The method of Beutler et al., (1963) was followed in estimating the level of reduced glutathione (GSH). First, $0.2 \mathrm{ml}$ of sample was added to $1.8 \mathrm{ml}$ of distilled water and $3 \mathrm{ml}$ of the precipitating solution was mixed with sample. Thereafter, the mixture was allowed to stand for five (5) minutes and then filtered. At the end of the fifth minutes, $1 \mathrm{ml}$ of filtrate was added to $4 \mathrm{ml}$ of $0.1 \mathrm{M}$ phosphate buffer. Then $0.5 \mathrm{ml}$ of Ellman's reagent was added. A blank was also prepared containing $4 \mathrm{ml}$ of $0.1 \mathrm{M}$ phosphate buffer, $1 \mathrm{ml}$ of diluted precipitating solution ( 3 parts to 2 parts of distilled water) and $0.5 \mathrm{ml}$ of Ellman's reagent. The optical density was measured at $412 \mathrm{~nm}$ with GSH being proportional to the absorbance at this wavelength as estimated from the GSH standard curve.

Estimation of Tissue Lipid Peroxidation: The level of Thiobarbituric acid reactive substances (TBARS) which is an index of lipid peroxidation was determined by the method of Varshney and Kale (1990). An aliquot of $0.4 \mathrm{ml}$ of the sample was mixed with $1.6 \mathrm{ml}$ of Tris-KCL buffer to which $0.5 \mathrm{ml}$ of $30 \%$ TCA was added. Then $0.5 \mathrm{ml}$ of $0.75 \%$ TBA was added and placed in a water bath for 45 minutes at $80^{\circ} \mathrm{C}$. This was then cooled in ice and centrifuged at $3000 \mathrm{~g}$. The clear supernatant was collected and absorbance measured against a reference blank of distilled water at 532nm. Liquid peroxidation in units/mg protein or gram tissue was computed with a molar extinction coefficient of $1.56 \times 10^{5} \mathrm{M}^{-1} \mathrm{CM}^{-1}$. Values of TBAS are reported in terms of malondialdehyde (MDA) and expressed as $\mu$ mole $\mathrm{MDA} / \mathrm{g}$ tissue. The amount of MDA in the samples was quantified using a molar extinction coefficient of $1.56 \times 10^{5} \mathrm{~m} / \mathrm{cm}$.

Analysis of Data: Results obtained in the study are presented as Mean \pm SD. Statistical analysis was performed using the Statistical Package for Social
Sciences (SPSS) software. The one-way analysis of variance (ANOVA) was utilized in comparing the degree of significance of different parameters estimated and the difference between means were considered to be significant at $\mathrm{p}<0.05$.

\section{RESULTS AND DISCUSSION}

HPLC Analysis of H. sabdariffa Anthocyanins: HPLC analysis of anthocyanin extract of $H$. sabdariffa calyces (Fig 1) showed that it contains several anthocyanins with the main ones been malvidin-3-Oglucoside, delphinidin-3-monoglucoside, cyanidin-3monoglucoside and petunidin-3-monoglucoside based on their retention time from published data. This result is in agreement with the work of Ologundudu et al., (2010) who identified delphinidin-3-monoglucoside, cyaniding-3-monoglucoside and petunidin-3monoglucoside as the predominant anthocyanins in $H$. sabdariffa calyces. Obouayeba et al., (2015) who did phytochemical characterisation and antioxidant activity analysis of Hibiscus sabdariffa (Malvaceae) calyx extracts also identified delphinidin 3-Oglucoside and cyanidin 3-O-glucoside as the major anthocyanins in Hibiscus sabdariffa (Malvaceae) calyx. In addition, Abeda et al., (2015) revealed that cyanidin-3-O-sambubioside is the predominant anthocyanin in Hibiscus sabdariffa callus. This results thus supports the implication of anthocyanins as being responsible for the antioxidant properties of Hibiscus sabdariffa (Milbury et al., 2010).

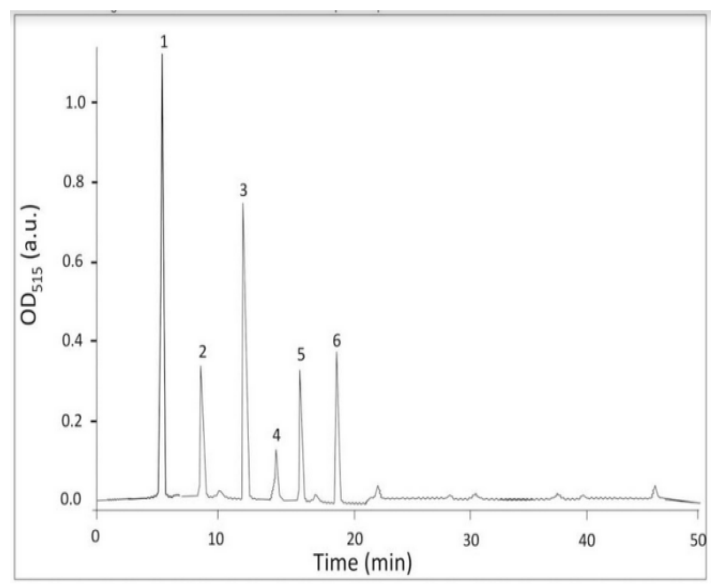

Fig 1: HPLC chromatogram of Hibiscus sabdariffa anthocyanins.

Effects of $H$. sabdariffa Anthocyanins on Tissue Oxidative Parameters: Exposure to $\mathrm{Cd}$ significantly reduced $(\mathrm{p}<0.05)$ GSH levels and glutathione-stransferase activity in the plasma and tissues assayed as shown in Tables 1 and 2 respectively. This was accompanied by increased lipid peroxidation in the tissues of Cd-exposed rats (Table 3). 
Table 1: Effect of $H$. sabdariffa anthocyanin on the levels of Reduced Glutathione (GSH) in the serum and tissues of Cd-exposed rats

\begin{tabular}{llcc}
\hline \multirow{2}{*}{ Groups } & \multicolumn{3}{c}{ Reduced Glutathione (GSH) } \\
\cline { 2 - 4 } & Serum & Liver & Kidney \\
\hline 1 & $35.60 \pm 1.12^{\mathrm{a}}$ & $58.23 \pm 2.14^{\mathrm{a}}$ & $57.03 \pm 2.44^{\mathrm{a}}$ \\
2 & $25.69 \pm 1.21$ & $33.24 \pm 1.89^{\mathrm{b}}$ & $23.03 \pm 2.32^{\mathrm{b}}$ \\
3 & $36.08 \pm 1.30^{\mathrm{a}}$ & $60.43 \pm 2.01^{\mathrm{a}}$ & $56.89 \pm 2.90^{\mathrm{c}}$ \\
4 & $30.40 \pm 1.04^{\mathrm{c}}$ & $58.90 \pm 2.60^{\mathrm{a}}$ & $39.38 \pm 2.50^{\mathrm{d}}$ \\
5 & $34.90 \pm 1.23^{\mathrm{a}}$ & $59.00 \pm 1.89^{\mathrm{a}}$ & $40.12 \pm 2.12^{\mathrm{d}}$ \\
\hline
\end{tabular}

作 the same column with different superscripts differ significantly $(P<0.05)$ within the same tissue. Groups:1 (Control), 2 (Cd), 3 (Anthocyanin), 4 (Anthocyanin Pre-Cd), 5 (Anthocyanin Post-Cd).

Table 2: Effect of $\mathrm{H}$. sabdariffa anthocyanin on the activity of glutathione-s-transferase (GST) in the serum and tissues of Cdexposed rats

\begin{tabular}{llll}
\hline \multirow{2}{*}{ Groups } & \multicolumn{3}{c}{ Glutathione-s-transferase (GST) } \\
\cline { 2 - 4 } & Serum & Liver & Kidney \\
\hline 1 & $44.37 \pm 1.12^{\mathrm{a}}$ & $26.45 \pm 0.56^{\mathrm{a}}$ & $10.01 \pm 1.10^{\mathrm{a}}$ \\
2 & $22.50 \pm 1.11^{\mathrm{b}}$ & $12.80 \pm 0.67^{\mathrm{b}}$ & $07.22 \pm 1.12^{\mathrm{b}}$ \\
3 & $43.10 \pm 1.14^{\mathrm{a}}$ & $25.42 \pm 0.48^{\mathrm{a}}$ & $10.90 \pm 0.98^{\mathrm{a}}$ \\
4 & $41.60 \pm 1.16^{\mathrm{a}}$ & $22.56 \pm 0.57^{\mathrm{c}}$ & $09.01 \pm 1.00^{\mathrm{c}}$ \\
5 & $41.88 \pm 0.90^{\mathrm{a}}$ & $23.02 \pm 0.69^{\mathrm{c}}$ & $09.96 \pm 1.05^{\mathrm{c}}$ \\
\hline
\end{tabular}

Values are presented as mean $\pm S D$ and as units/ml (in serum) and umol CNB-GSH complex formed/min/mg protein (in other tissues). $n=5$. Values on the same column with different superscripts differ significantly $(P<0.05)$ within the same tissue. Groups:1 (Control), 2 (Cd), 3 (Anthocyanin), 4(Anthocyanin Pre-Cd), 5 (Anthocyanin Post-Cd).

Table 3: Effect of $\boldsymbol{H}$. sabdariffa anthocyanin on the levels of Malondiadehyde (MDA) in the tissues of Cd-exposed rats

\begin{tabular}{lll}
\hline \multirow{2}{*}{ Groups } & \multicolumn{2}{l}{ Malondiadehyde (MDA) } \\
\cline { 2 - 3 } & Liver & Kidney \\
\hline 1 & $76.50 \pm 2.02^{\mathrm{a}}$ & $52.14 \pm 2.22^{\mathrm{a}}$ \\
2 & $115.64 \pm 2.14^{\mathrm{b}}$ & $106.26 \pm 2.11^{\mathrm{b}}$ \\
3 & $72.30 \pm 2.12^{\mathrm{a}}$ & $49.05 \pm 2.20^{\mathrm{a}}$ \\
4 & $97.78 \pm 3.50^{\mathrm{c}}$ & $70.04 \pm 2.01^{\mathrm{c}}$ \\
5 & $97.01 \pm 2.08^{\mathrm{c}}$ & $70.01 \pm 2.08^{\mathrm{c}}$ \\
\hline
\end{tabular}

Values are presented as mean $\pm S D$ and as $\mu$ mole/mg protein. $n=5$. Values on the same column with different superscripts differ significantly $(P<0.05)$ within the same tissue. Groups:1 (Control), 2 (Cd), 3 (Anthocyanin), 4 (Anthocyanin Pre-Cd), 5 (Anthocyanin Post-Cd).

Table 4: Effect of $H$. sabdariffa anthocyanin on the activity of Catalase in the tissues of Cd-exposed rats

\begin{tabular}{lll}
\hline \multirow{2}{*}{ Groups } & \multicolumn{2}{l}{ Catalase (CAT) } \\
\cline { 2 - 3 } & Liver & Kidney \\
\hline 1 & $35.99 \pm 2.10^{\mathrm{a}}$ & $29.04 \pm 0.56^{\mathrm{a}}$ \\
2 & $22.23 \pm 2.01^{\mathrm{b}}$ & $15.76 \pm 0.59^{\mathrm{b}}$ \\
3 & $40.45 \pm 1.87^{\mathrm{c}}$ & $31.56 \pm 0.41^{\mathrm{a}}$ \\
4 & $29.57 \pm 1.59^{\mathrm{d}}$ & $19.80 \pm 0.62^{\mathrm{c}}$ \\
5 & $30.60 \pm 1.66^{\mathrm{d}}$ & $20.65 \pm 0.46^{\mathrm{c}}$ \\
\hline Values are presented as mean $\pm S D$ and as mmoles $\mathrm{H}_{2} \mathrm{O}_{2}$ consumed min ${ }^{-1} \mathrm{mg}^{-}$ \\
${ }^{\text {I }}$ protein. $n=5$. Values on the same column with different superscripts differ \\
significantly $(P<0.05)$ within the same tissue. Groups: 1 (Control), $2(\mathrm{Cd}), 3$ \\
(Anthocyanin), $\mathbf{4}$ (Anthocyanin Pre-Cd), 5 (Anthocyanin Post-Cd).
\end{tabular}

Table 5: Effect of $H$. sabdariffa anthocyanin on the activity of Superoxide Dismutase (SOD) in the tissues of Cd-exposed rats

\begin{tabular}{lll}
\hline Groups & \multicolumn{2}{l}{ Superoxide Dismutase (SOD) } \\
\cline { 2 - 3 } & Liver & Kidney \\
\hline 1 & $49.23 \pm 1.23^{\mathrm{a}}$ & $32.56 \pm 2.34^{\mathrm{a}}$ \\
2 & $25.69 \pm 1.65^{\mathrm{b}}$ & $22.34 \pm 2.56^{\mathrm{b}}$ \\
3 & $56.70 \pm 1.78^{\mathrm{c}}$ & $36.01 \pm 3.63^{\mathrm{c}}$ \\
4 & $33.78 \pm 1.29^{\mathrm{d}}$ & $29.12 \pm 2.10^{\mathrm{d}}$ \\
5 & $35.90 \pm 1.29^{\mathrm{d}}$ & $29.99 \pm 2.38^{\mathrm{d}}$ \\
\hline
\end{tabular}

Values are presented as mean $\pm S D$ and as $\mu$ mole/mg protein. $n=5$. Values on the same column with different superscripts differ significantly $(P<0.05)$ within the same tissue. Groups:1 (Control), 2 (Cd), 3 (Anthocyanin), 4 (Anthocyanin Pre-Cd), 5 (Anthocyanin Post-Cd).

These can be attributed to the oxidative stress induced by $\mathrm{Cd}$ and is in line with earlier reports (Atagana and Asagba, 2015; Al Groom and Al- Kubaisy, 2016, Baomy, 2016). Baiomy, (2016) showed that Cd caused increase in lung tissue malondialdehyde and reduced the activity of glutathione peroxidase and other antioxidant enzymes, while the work of $\mathrm{Al}$ Groom and Al- Kubaisy (2016) indicated that Cd administration significantly reduced glutathione (GSH) concentration, but increased malondialdehyde levels in rat erythrocytes. Membrane lipid peroxidation has been shown as an important early manifestation of $\mathrm{Cd}$ induced oxidative damage to the liver and kidney playing a major role in the induction of toxic lesions (Mafulul and Okoye, 2012 and Embugushiki et al., (2013). This study confirms that exposure to cadmium causes a significant increase in membrane lipid peroxidation in the liver and kidneys of rats.

Reduced glutathione (GSH) is involved in the detoxification of reactive intermediates by quenching free radicals directly or by conjugation and hydro peroxide reduction. It role in maintaining balance of cellular redox processes cannot be overestimated (Volodymyr, 2012). Thus, the depletion of GSH facilitates the production of ROS leading to oxidative stress and increased lipid peroxidation as observed in this study. But pre-treatment and post-treatment with HSA blocked this phenomenon effectively. This may be due to the enhancement of the activity of GST by the extracts (Table 1).Usoh et al., (2005) noted that the level of GSH in cells and tissues depends greatly on the activity of GST. It is thus not surprising that pretreatment and post-treatment of Cd-exposed rats with HSA significantly induced the activity of GST in the liver and kidney and reversed its Cd-induced depletion. It can therefore be said that the effects of HSA against $\mathrm{Cd}$ toxicity, observed in this study, may be due to increased GST activity with concomitant increase in the levels of GSH. Another reason for this observation may be direct quenching of the reactive metabolites induced by $\mathrm{Cd}$ toxicity by HSA. Extracts from HS have previously been reported to have this effect (Mossalam et al., 2011).

The activities of endogenous antioxidants such as catalase and superoxide dismutase were also studied as presented in Tables 4 and 5 respectively. $\mathrm{Cd}$ exposure caused a significant decrease $(\mathrm{p}<0.05)$ in tissue SOD and CAT activities accompanied by increase in MDA levels (Table 2). These findings are consistent with Atagana and Asagba, (2015) who 
reported significant decrease in the activities of tissue SOD and CAT following Cd exposure.Patra et al., (2011) noted that Catalase, superoxide dismutase (SOD), and glutathione peroxidase are the three primary antioxidant enzymes of the endogenous defence systems needed for the removal of reactive oxygen species and protection of cells, tissues and organs from oxidative damage. The increase in SOD and CAT activities observed in the liver and kidney, relative to other tissues, may be due to high induction of SOD in these tissues being the major targets of $\mathrm{Cd}$ accumulation and toxicity.

In this study, pre-treatment and post-treatment with HSA improved tissue SOD and CAT activities and this observation is consistent with the work of Usoh et al., (2005). The ability of $H$. sabdariffa anthocyanins to protect and liver and other tissues is shown by the significant $(\mathrm{P}<0.05)$ increase in the activity of CAT and SOD in the liver and other tissues when compared with rats exposed to $\mathrm{Cd}$ alone. This again shows that $H$. sabdariffa anthocyanins are potent antioxidant and is in consonance with the reported protective effects of antioxidant nutrients against $\mathrm{Cd}$-induced oxidative stress and lipid peroxidation in the liver and kidney (Asagba et al., 2010and Mafulul and Okoye, 2012).

Conclusion: The results of this study confirm the antioxidant capacity of $H$. sabdariffa anthocyanins in ameliorating $\mathrm{Cd}$-induced oxidative stress when administered pre and post $\mathrm{Cd}$ exposure. It is therefore both curative and protective in its effect against $\mathrm{Cd}$ toxicity and can be used for the treatment of $\mathrm{Cd}$ intoxication in populations where $\mathrm{Cd}$ exposure due to environmental pollution is still rampant.

\section{REFERENCES}

Aaseth, J; Crisponi, G; Ole, A (2016). Chelation Therapy in the Treatment of Metal Intoxication. Academic Press. p. 388. ISBN 9780128030721

Abeda, ZH; Sie, RS; Ayolie, K; Yapo, SES; Coulibaly, S; Kouassi, KM; Kouakou, TH (2015). Free Radical Scavenging Properties and Antioxidant Activities of Some Anthocyanins Purified from Roselle (Hibiscus sabdariffa L.) Callus Using In-Vitro Tests. Res. J. Pharma. Biol. Chem. Sci. 6(6):320-329

Al Groom, RM; Al- Kubaisy, K (2016). Anthocyanin-Rich Red Dye of Hibiscus sabdariffa L. Calyx Modulates $\mathrm{CdCl} 2-$ Induced Hypochromic Microcytic Anaemia and Oxidative Stress in Rat Red Blood Cells. $J$. Environ. 5 (1): 13-18.

Andujar, P; Bensefa-Colas, L; Descatha, A (2010). Intoxication aiguëetchronique au cadmium. Res. Rev. Med Intern. 31(2):107-115.
Arroyo, VS; Flores, KM; Ortiz, LB; Gómez-Quiroz, LE; Gutiérrez-Ruiz, MC (2012). Liver and cadmium toxicity. J. Drug Metab. Toxicol. S5:001.

Asagba, SO (2010). Biochemical Changes in Urine and Plasma of Rats in Food-chain Mediated Cadmium Toxicity. Nig. J. Biochem Mol. Bio. 25 (1): 9 - 17.

Atagana, OS; Asagba, SO (2015). Protective effects of honey against cadmium-induced alteration of some biochemical parameters in rats. J. Toxicol. Environ Chem., 96(10):1557-1563.

Baiomy, AA; Mansour, AA (2016). Genetic and histopathological responses to cadmium toxicity in rabbit's kidney and liver: Protection by Ginger (Zingiberofficinale). Biol. Trace Elem. Res. 170(2):320-9.

Beutler, E; Duron, O; Kelly, BM (1963). Improved method for the determination of blood glutathione. J. Lab. Clin. Med.; 61:882-888.

Callegaro, MG; Milbradt, BG; Diettrich, T; Alves, E; Duarte, FA; Flores, EM; Dressler, VL; Silva, LP; Emanuelli, $T$ (2010). Influence of cereal bran supplement on cadmium effects in growing rats. Hum. Exp. Toxicol. 6:467-76.

Cuypers, A; Plusquin, M; Remans, T; Jozefczak, M; Keunen, E; Gielen, H; Opdenakker, K; Nair, AR; Munters, E; Artois, TJ; Nawrot, T; Van gronsveld, J; Smeets, K (2010). Cadmium stress: an oxidative challenge. Biometals 23:927-940.

Drust, RW; Wrolstad, RE (2001). Separation and characterization of Anthocyanins by HPLC. In: Current Protocols in Foods Analytical Chemistry, Wrolstad, R. E., Eds., John Wiley and Sons: New York, pp. 1-13.

Embugushiki, RE; Mafulul, SG; Okoye, ZSC (2013). Protective effect of carrot juice pretreatment on cadmium-induced oxidative cytotoxic damage to some rat tissues. J. Pharm Bio. Sci. 7 (6):55-62.

Gaurav, D; Preet, S; Dua, KK (2010). Chronic cadmium toxicity in rats: treatment with combined administration of vitamins, amino acids, antioxidants and essential metals. J. Food Drug Analysis. 18 (6): 464-470.

Hong, V; Wrolstad, RE (1990). Use of HPLC separation/photodiode array detection for characterization of anthocyanins. J. Agric. Food Chem. 38: 708-715.

Horiguchi, H; Oguma, E; Kayama, F (2011). Cadmium Induces Anemia through Interdependent Progress of Hemolysis, Body Iron Accumulation, and Insufficient Erythropoietin Production in Rats. Toxicol. Sci. 122(1), 198-210 
Jabeen, F; Chaudhry, AS (2011). Effects of sodium selenite in cadmium chloride induced hepatoxicity in male sprague-dawley rats. Pak. J. Zool., 43(5): 957-965.

Mafulul, SG; Okoye, ZSC (2012). Protective effect of presupplementation with selenium on cadmium-induced oxidative damage to some rat tissues. Int. J. Biol. Chem. Sci. 6(3):1128-1138.

McCarty, MF (2012). Zinc and multi-mineral supplementation should mitigate the pathogenic impact of cadmium exposure. Med. Hypotheses, 79, 642-648.

Miguel, MG (2011) Anthocyanins: Antioxidant and/or antiinflammatory activities. J. Appl. Pharm. Sci. 01 (06): 07-15.

Milbury, PE; Vita, JA; Blumberg, JB (2010). Anthocyanins are bioavailable in humans following an acute dose of cranberry juice. J. Nutr.; 140: 1099-104.

Misra, HP; Fridovich, I (1972). The Role of Superoxide Anion in the Autoxidation of Epinephrine and a Simple Assay for Superoxide Dismutase. J. Bio. Chem. 247: 3170-3176

Mossalam, HH; Aty, OA; Morgan, AE; Youssaf, EN; Mackawy, AMH (2011). Biochemical and ultrastructure studies of the antioxidant effect of aqueous extract of Hibiscus sabdariffa on the Nephrotoxicity Induced by organophosphorous pesticide (Malathion) on the adult albino rats. Life Sci. J. 8(5), 561-574.

Obouayeba, AP; Okoma, KM; Diarrassouba, M; Diabaté, S; Kouakou, TH (2015). Phytochemical Characterization and Antioxidant Activity of Hibiscus sabdariffa (Malvaceae) Calyx Extracts. J. Agri. Food Applied Sci. 3(2):39-46.

Ognjanović, BI; Pavlović, SZ; Maletić, SD; Zikić, RV; Stajn, AS; Radojicić, RM; Saicić, ZS; Petrović, VM (2010). Protective influence of vitamin E on antioxidant defense system in the blood of rats treated with cadmium. Physiol. Res. 52(5):563570 .
Ologundudu, A; Ologundudu, AO; Ololade, IA; Obi, FO (2010). Effect of Hibiscus sabdariffa anthocyanins on 2,4-dinitrophenylhydrazineinduced hematotoxicity in rabbits. Afr. J. Biochem. Res. 3: 140-144.

Onwuka, FC; Erhabor, O; Eteng, MU; Umoh, IB (2010). Ameliorative effect of cabbage extract on cadmium-induced changes on hematology and biochemical parameters of albino rats. J. Toxico. Environ Health Sci. 2(2):11-16.

Sinha, AK (1972). Colorimetric assay of catalase. Analy. Biochem. 47(2):389-394.

Usoh, IF; Akpan, EJ; Etim, EO; Farombi, EO (2005). Antioxidant actions of dried flower extracts of Hibiscus sabdariffa L. on sodium arsenite Induced oxidative stress in rats. Pakistan J. Nutri. 4(3), 135-141.

Varshney, R; Kale, RK (1990). Effects of calmodulin antagonists on radiation-induced lipid peroxidation in microsomes. IntJ. Radiat.Biol. 58(5):733-743.

Vesey, DA (2010). Transport pathways for cadmium in the intestine and kidney proximal tubule: Focus on the interaction with essential metals. Toxicol. Lett.198, 13-19.

Volodymyr, IL (2012). Glutathione Homeostasis and Functions: Potential Targets for Medical Interventions. J. Amino Acids.2012:1-26.

Yang, H; Shu, Y (2015). Cadmium Transporters in the Kidney and Cadmium-Induced Nephrotoxicity. Int. J. Mol. Sci.16: 1484-1494.

Zarros, A; Skandali, N; Al-Humadi, H; Liapi, C. (2008). Cadmium (Cd) as a carcinogenetic factor and its participation in the induction of lung cancer. Pneumon. 21:172-177. 